\title{
Monthly occurrence and prevalence of viral haemorrhagic septicaemia virus (VHSV) in whiting Merlangius merlangus
}

\author{
C. Altuntaş, H. Ogut* \\ Karadeniz Technical University, Faculty of Marine Sciences, Department of Fisheries Technology Engineering, \\ 61530 Camburnu-Surmene, Trabzon, Turkey
}

\begin{abstract}
A field survey was carried out to determine the occurrence and spread of viral haemorrhagic septicaemia virus (VHSV) in whiting Merlangius merlangus (L.), a key prey species in the southeastern Black Sea region. In March, April, September and December 2007 and monthly in 2008, 70 to 105 M. merlangus captured by gill nets were examined in pools of 7 fish per pool (total number of fish =1603). After determining the seasonal occurrence of VHSV in whiting, 43, 80 and 88 whiting were sampled individually in January, February and March 2009, respectively, to determine age and size of whiting commonly infected with VHSV. The samples were tested in duplicate using BF-2 and EPC cell lines for virus isolation. Positive cultures (those demonstrating cytopathic effect, [CPE]), were tested further with a commercial ELISA kit to confirm that the observed CPE was caused by VHSV. VHSV was detected in M. merlangus only between February and April following a drop in the surface water temperature to $9^{\circ} \mathrm{C}$. All infected fish from the sampled whiting were asymptomatic carriers with low levels of virus. The estimated prevalence from pooled samples ranged between $1.35 \%$ (2.5 to 97.5 percentiles; 0.04 to $7.32 \%$ ) to $3.14 \%$ (0.36 to $10.95 \%$ ), whereas prevalence estimated from individual sampling was 7, 5 and $1 \%$ in January, February and March, respectively. Individual sampling also revealed that prevalence was higher among young fish (1 to $1.5 \mathrm{yr}$ old) and decreased with increasing age. This is the first report of VHSV infection in whiting in the Black Sea.
\end{abstract}

KEY WORDS: VHSV $\cdot$ Whiting $\cdot$ Merlangius merlangus $\cdot$ Survey $\cdot$ Turkey $\cdot$ Black Sea

\section{INTRODUCTION}

Viral haemorrhagic septicaemia (VHS) is one of the most important viral fish diseases in Europe (Wolf 1988, Hill 1992, Olesen 1998, Smail 1999) causing up to $100 \%$ mortality in cultured and wild fish. A disease similar to VHS was first described in rainbow trout Oncorhynchus mykiss in 1962 (Jensen 1963, 1965) and the first isolation of VHS virus (VHSV) from wild fish in the marine environment was reported from cod Gadus morhua L. in 1979 (Jensen et al. 1979, Jørgensen \& Olesen 1987). Since then VHSV has been isolated from an increasing range of free-living fish species in the marine environment around the world. Indeed, the presence of VHSV has been reported in at least 83 species of marine and freshwater fish in the past 2 decades and 11 more fish species have been shown to be experimentally susceptible to VHSV (OIE 2009). Based on these data, and also partly due to an increased awareness, it is expected that the known host and geographical ranges of VHSV will continue to expand.

Except for a few studies, the spread and occurrence of VHSV in marine fish species in the Black Sea remain unclear. The first isolation of VHSV in the Black Sea region was from freshwater rainbow trout in Georgia (Einer-Jensen et al. 2004). Turbot Psetta maxima is the only marine fish species in which VHSV was reported with relatively high prevalence $(21 \%$ in spawners and 
$1.5 \%$ in young fish) in the Black Sea (Nishizawa et al. 2006). These isolates obtained from the Black Sea region belong to the genotype Ie (Einer-Jensen et al. 2004, Nishizawa et al. 2006).

Several factors such as genetics, age, species, stress and environmental variables influence susceptibility of fish hosts to VHS (Hedrick et al. 2003, Skall et al. 2005). Temperature, a limiting factor for the replication of the virus, is one of the most important environmental conditions that influences the occurrence and spread of the virus. Although VHS is considered a cold water disease with most outbreaks associated with high mortality occurring at temperatures ranging from 9 to $12^{\circ} \mathrm{C}$ in springtime when ambient water temperatures fluctuate (OIE 2009), VHSV has been isolated from wild fish in water temperatures ranging between 2 and $20^{\circ} \mathrm{C}$ (Gastric \& de Kinkelin 1980, Meyers et al. 1994, Takano et al. 2001). However, in vivo and in vitro tolerances to temperatures and virulences may show differences among VHSV genogroups (Hedrick et al. 2003). Therefore, accumulated evidence on temperature dependence of VHSV suggests that the occurrence of VHS in the marine environment may fluctuate with seasons. However, there are scarce data reporting on the monthly occurrence of VHSV in the wild in Turkey or in other parts of the world where VHSV has been detected.

In the present study, monthly occurrence and prevalence of VHSV in a key species, whiting Merlangius merlangus (L.), an important prey of many carnivorous fish species including whiting itself, was determined in a region of the Black Sea. Our hypothesis was that, considering the water temperature where whiting live is almost always below $15^{\circ} \mathrm{C}$, VHSV would be present in whiting throughout year and would not show seasonal variation in prevalence in the Black Sea. This is also the first report of VHSV in whiting in the Black Sea.

\section{MATERIALS AND METHODS}

Fish. Whiting were sampled in the months of March, April, May, August and December in 2007 and monthly from January to December in 2008 to determine occurrence and prevalence of VHSV. Whiting were captured using gill nets $\left(40^{\circ} 58^{\prime} \mathrm{N}, 39^{\circ} 53^{\prime} \mathrm{E}\right.$; Fig. 1) set at midnight and pulled up at dawn the following morning, from depths of 30 to $45 \mathrm{~m}$. Only whiting that were newly captured and present in the gill nets for a relatively short time were collected, pooled ( 7 fish per pol) in separate plastic bags, and immediately transferred to coolers with ice. The collected samples were brought to the laboratory, the length and weight of each fish measured, any external disease signs recorded, and samples from kidney, spleen and liver were collected aseptically (all equipment was disinfected between the processing of each pool) into plastic bags for homogenization with a stomacher containing Earl's minimal essential medium supplemented with antibiotics (100 IU penicillin $\mathrm{ml}^{-1}$, $100 \mu \mathrm{g}$ streptomycin $\left.\mathrm{ml}^{-1}\right)$ and an antifungal $(0.25 \mu \mathrm{g}$ amphotericin-B $\mathrm{ml}^{-1}$ ).

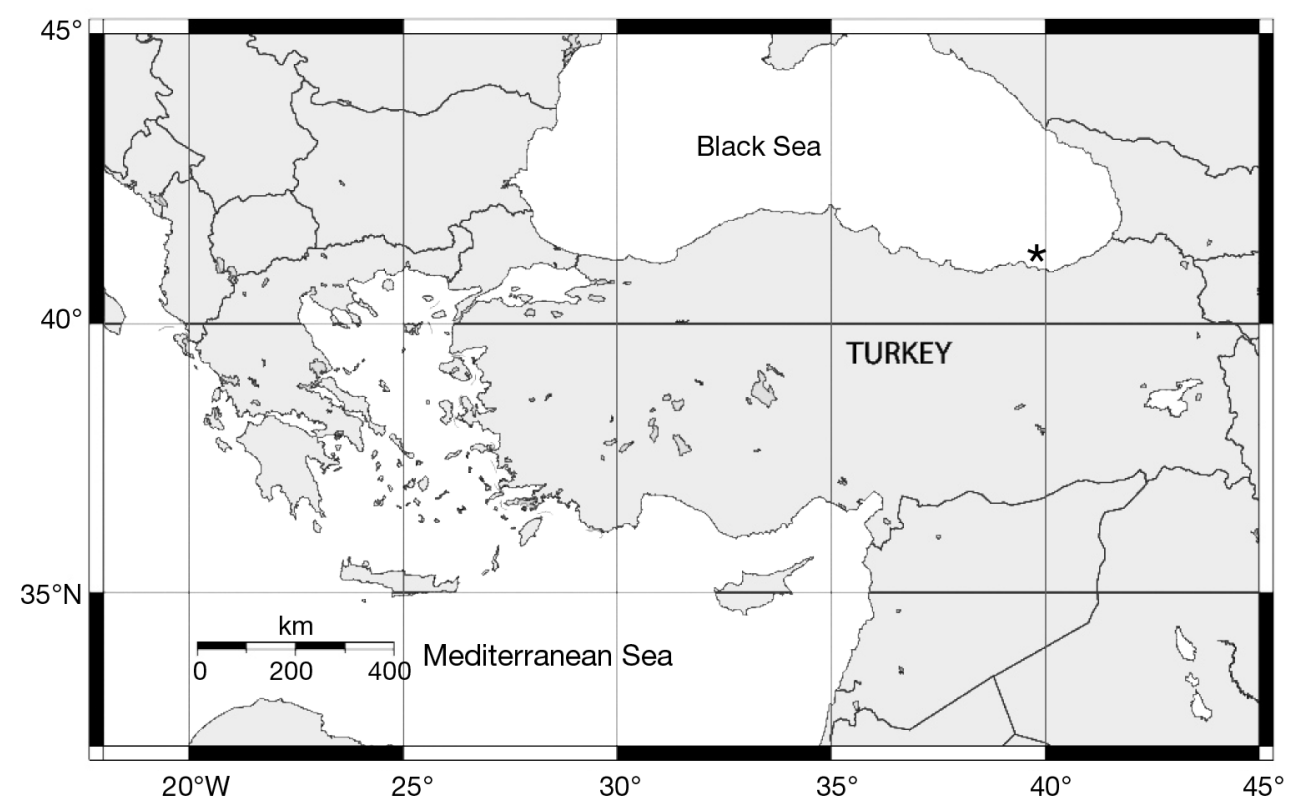

Fig. 1. Black Sea region showing the sampling point $(*)$ for the present study 
Prevalence values were estimated from pooled samples as described by Kline et al. (1989) and Hauck (1991) and compared with the prevalence values obtained from the individual sampling (Cowling et al. 1999).

Individual sampling. After determining the seasonal occurrence of VHSV in whiting in 2007-08, individual samples of whiting were collected in 2009 by hook and line in the same region (Fig. 1) during the season when VHSV was previously found to be prevalent in whiting. The specimens were collected individually in separate Whirl-packs and brought to the laboratory on ice. On the same day, weights and lengths of each fish were measured, and their sexes were recorded before virological processing, as described in the next section. The age of the fish was estimated from an age-length von Bertalanffy equation reported for whiting in the same area (Ciloglu et al. 2001):

$$
L_{t}=L_{\infty}\left[1-\mathrm{e}^{-\mathrm{k}\left(t-t_{0}\right)}\right]
$$

where $L_{t}$ is length at time $t_{1} L_{\infty}$ is the maximum length fish can grow, and $\mathrm{k}$ is the constant. The following values were used: $L_{\infty}=52.2 \mathrm{~cm}, \mathrm{k}=0.092$ and $t_{0}=$ -1.759 for females; and $L_{\infty}=37.19 \mathrm{~cm}, \mathrm{k}=0.114$ and $t_{0}=$ -2.390 for males.

Virological examination. After adjusting to produce a 1:10 ratio of sample to diluent, the samples were centrifuged for $20 \mathrm{~min}$ at $4000 \times g$ at $4^{\circ} \mathrm{C}$. The supernatants $(1: 10$ in pooled samples, $1: 10$ and $1: 100$ in individual samples) were then inoculated in duplicate onto $24 \mathrm{~h}$ old monolayer cultures of bluegill fry Lepomis macrochirus fibroblast (BF-2) and epithelioma papulosum cyprini (EPC) cell lines (Fijan et al. 1983) seeded in 24 well plates, with culture medium (minimal essential medium [MEM] with Earl's salts [EMEM]) supplemented with antibiotics (100 IU penicillin $\mathrm{ml}^{-1}, 100 \mu \mathrm{g}$ streptomycin $\mathrm{ml}^{-1}$ ), antifungal agents $\left(0.25 \mu \mathrm{g}\right.$ amphotericin $\left.\mathrm{B} \mathrm{ml}^{-1}\right)$ and $10 \%$ fetal bovine serum. The cultures were incubated at $15^{\circ} \mathrm{C}$ for $14 \mathrm{~d}$ and checked once every $3 \mathrm{~d}$. The samples showing no cytopathic effect (CPE) were blind-passaged, and CPE positive samples were reinoculated to verify that the observed CPE was not the result of non-specific toxicity before testing with a commercial ELISA kit (Test-Line, Clinical Diagnostics) following the manufacturer's instructions. Specificity controls (infectious pancreatic necrosis virus [IPNV] and infectious haematopoietic necrosis virus [IHNV]) were also used with the positive and negative controls supplied by the kit.

Determining effect of environmental temperature on virus viability. During summer the highest surface water temperature is around $26^{\circ} \mathrm{C}$ in the Black Sea, though the temperatures at depths lower than $30 \mathrm{~m}$ are always below $17^{\circ} \mathrm{C}$. To determine potential effects of this high temperature shock during sampling on the viability of the virus, VHSV was exposed to $26^{\circ} \mathrm{C}$ for periods ranging from 1 to $7 \mathrm{~h}$. For this purpose, a stock culture of VHSV in MEM of known titre was divided into 9 vials; 7 vials were kept at $26^{\circ} \mathrm{C}$ and 2 vials were kept refrigerated as controls. VHSV was titred to determine the level of change in viability after exposure to $26^{\circ} \mathrm{C}$ for various duration of time.

\section{RESULTS}

\section{Virological examination}

VHSV was detected in whiting during winter through to early spring at low levels. Of the 1603 fish examined, none had any signs of disease, e.g. haemorrhages on the body surfaces or on the viscera. VHSV was only detected in the samples collected in February, March and April 2008. Similarly virus was also present in whiting sampled over the same months in 2007. In all samples taken in 2007 and 2008, there was a maximum of 2 pools that tested positive for VHSV (Table 1). The maximum level of prevalence estimated from pooled samples (Cowling et al. 1999) was 3.14\% for 2 positive pools out of 10 . However, the upper percentile (97.5) used as confidence interval was 3 times higher than the estimated prevalence indicating high variation in the data.

The seasonal fluctuation in surface and bottom water temperatures is given in Fig. 2. Bottom temperatures stayed below $15^{\circ} \mathrm{C}$ except in December, indicating a seasonal turnover. Bottom temperatures were warmer than surface temperatures between December and March. Surface water temperature dipped $\left(9^{\circ} \mathrm{C}\right)$ in February when VHSV was first detected in whiting.

$\mathrm{Up}$ to $7 \mathrm{~h}$ exposure to $26^{\circ} \mathrm{C}$ had no effect on the viability of VHSV (Fig. 3), indicating that short exposures $(<3 \mathrm{~h})$ of the samples to high water temperatures during summer did not bias monthly sampling. Moreover, the titer of virus that was incubated for $7 \mathrm{~h}$ at $4^{\circ} \mathrm{C}$ was slightly higher than the initial virus titers but not statistically different $(\mathrm{p}<0.05)$.

\section{Individual sampling}

A total of 211 fish belonging to various length classes (Fig. 4) were collected in January, February and March of 2009 (Table 2). The ratio of male to female fish (1:1.7) was identical to recently reported data (Ciloglu et al. 2001) indicating that the sample was representative of the stock in the area.

Prevalence of VHSV in whiting was the highest in 
Table 1. Merlangius merlangus. Monthly sampling scheme; ratio of VHSV-positive to total pools (bold ratios include VHSVpositive pools); mean $( \pm \mathrm{SD})$ fish length $(\mathrm{cm})$; mean $( \pm \mathrm{SD})$ fish weight $(\mathrm{g})$ per pool (mean weight of all fish in the sample at a given month, e.g. on 27/02/2008, 2 out of 10 pools were positive and mean weight of 70 fish was $21.53 \pm 4.45 \mathrm{~g})$; condition factor $(\mathrm{CF})=$ (weight $\times$ length $\left.{ }^{-3}\right) \times 100$; percent prevalence $(P)$ of infected individuals determined as $P=[1-(1-S / R) \times 1 / C]$ where $S=$ number of infected pools, $R=$ number of total pools and $C=$ number of individuals in each pool (Kline et al. 1989); and 2.5 and 97.5 percentiles for the correction of lower confidence interval bands calculated as described by Hauck (1991). Each sample pool consisted of 7 fish (i.e. 1603 fish examined in total). Dates are given as d/mo/yr

\begin{tabular}{|c|c|c|c|c|c|c|}
\hline $\begin{array}{l}\text { Sampling } \\
\text { date }\end{array}$ & $\begin{array}{l}\text { VHSV-positive/ } \\
\text { total pools }\end{array}$ & $\begin{array}{l}\text { Fish length } \\
\text { (cm) }\end{array}$ & $\begin{array}{l}\text { Fish weight } \\
\text { per pool }(\mathrm{g})\end{array}$ & $\mathrm{CF}$ & $\begin{array}{c}\text { Individual } \\
\text { prevalence }(\%)\end{array}$ & $\begin{array}{c}\text { Percentiles } \\
(2.5-97.5)\end{array}$ \\
\hline $15 / 03 / 2007$ & $2 / 10$ & $14.59 \pm 0.79$ & $23.84 \pm 3.72$ & 0.77 & 3.14 & $0.36-10.95$ \\
\hline 29/03/2007 & $0 / 12$ & $14.56 \pm 0.81$ & $24.51 \pm 3.84$ & 0.79 & 0 & \\
\hline $11 / 04 / 2007$ & $2 / 12$ & $14.73 \pm 0.74$ & $24.31 \pm 3.70$ & 0.76 & 2.57 & $0.3-9.02$ \\
\hline 24/04/2007 & $0 / 15$ & $13.84 \pm 0.92$ & $19.82 \pm 4.02$ & 0.75 & 0 & \\
\hline $10 / 05 / 2007$ & $0 / 15$ & $14.73 \pm 0.78$ & $22.12 \pm 3.60$ & 0.69 & 0 & \\
\hline $27 / 09 / 2007$ & $0 / 10$ & $15.35 \pm 0.97$ & $26.04 \pm 4.41$ & 0.72 & 0 & \\
\hline $17 / 12 / 2007$ & $0 / 12$ & $14.84 \pm 1.23$ & $26.29 \pm 6.34$ & 0.80 & 0 & \\
\hline $15 / 01 / 2008$ & $0 / 10$ & $14.80 \pm 1.26$ & $26.12 \pm 6.22$ & 0.81 & 0 & \\
\hline 07/02/2008 & $1 / 11$ & $15.53 \pm 1.09$ & $30.39 \pm 6.52$ & 0.81 & 1.35 & $0.04-7.32$ \\
\hline 27/02/2008 & $2 / 10$ & $14.59 \pm 1.13$ & $21.53 \pm 4.45$ & 0.69 & 3.14 & $0.36-10.95$ \\
\hline $12 / 03 / 2008$ & $2 / 10$ & $14.49 \pm 0.93$ & $21.48 \pm 3.05$ & 0.71 & 3.14 & $0.36-10.95$ \\
\hline 01/04/2008 & $1 / 11$ & $13.48 \pm 0.73$ & $19.30 \pm 3.15$ & 0.79 & 1.35 & $0.04-7.32$ \\
\hline $18 / 04 / 2008$ & $0 / 12$ & $14.53 \pm 1.17$ & $26.21 \pm 6.30$ & 0.85 & 0 & \\
\hline 23/05/2008 & $0 / 12$ & $14.20 \pm 0.84$ & $24.00 \pm 3.63$ & 0.84 & 0 & \\
\hline 20/06/2008 & $0 / 12$ & $14.67 \pm 0.59$ & $25.05 \pm 2.70$ & 0.79 & 0 & \\
\hline 24/07/2008 & $0 / 10$ & $13.29 \pm 1.66$ & $17.86 \pm 7.61$ & 0.76 & 0 & \\
\hline 21/08/2008 & $0 / 10$ & $12.49 \pm 1.72$ & $15.92 \pm 7.61$ & 0.82 & 0 & \\
\hline 24/09/2008 & $0 / 10$ & $14.75 \pm 1.11$ & $24.01 \pm 4.68$ & 0.75 & 0 & \\
\hline $25 / 10 / 2008$ & $0 / 11$ & $14.90 \pm 1.26$ & $27.07 \pm 6.51$ & 0.82 & 0 & \\
\hline 29/11/2008 & $0 / 14$ & $15.94 \pm 1.34$ & $32.49 \pm 8.85$ & 0.80 & 0 & \\
\hline Total & $10 / 229$ & & & & & \\
\hline
\end{tabular}

January $(7 \%)$ and decreased gradually in February (5\%) and March (1\%). Moreover, overall prevalence estimated in individual sampling was also higher than that estimated from pooled samples and ranged from 1.35 to $3.14 \%$ (Table 1 ).

Individual sampling showed that whiting could be infected up to age 3 with 25 and $11 \%$ prevalence among 1 and 1.5 yr old whiting, respectively (Fig. 4). Correspondingly, higher frequencies of VHSV were detected among smaller fish in 11.5 to $13.4 \mathrm{~cm} \mathrm{(33 \% )}$ and 13.5 to $15.4 \mathrm{~cm}$ (9.3\%) length classes (Fig. 5).

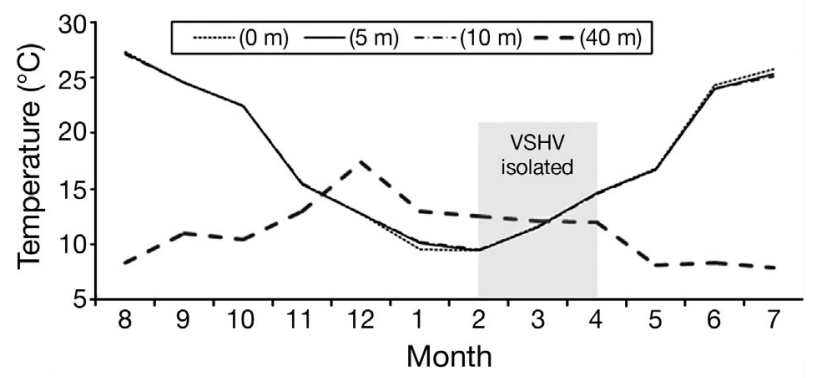

Fig. 2. Seasonal fluctuation of surface and bottom temperatures where whiting were sampled

\section{DISCUSSION}

Our results strongly indicate that VHSV is endemic in whiting, a key prey species for many predator species including whiting itself, in the coastal waters of the eastern Black Sea of Turkey. Young whiting (1 to $1.5 \mathrm{yr}$ old) were asymptomatically infected with very

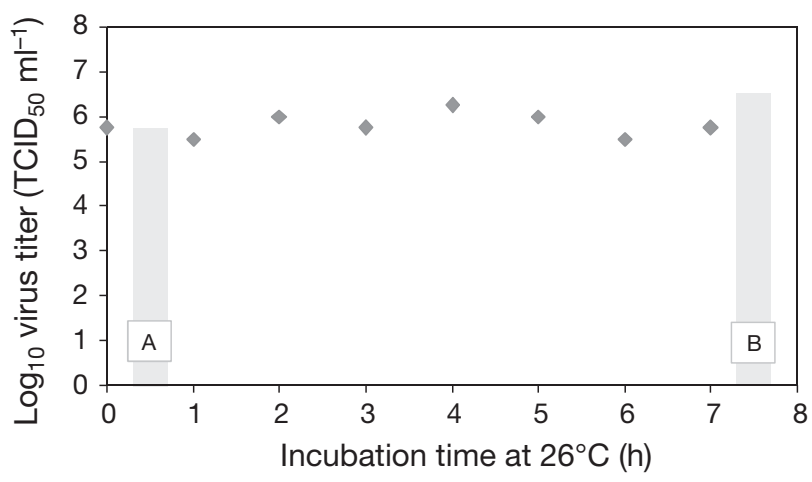

Fig. 3. VHSV titres at $1,2,3,4,5,6$ and $7 \mathrm{~h}$ incubation at $26^{\circ} \mathrm{C}$. Bar labelled $\mathrm{A}$ is the titre of stock virus before incubation and bar labelled B is titre of control virus stock incubated for $7 \mathrm{~h}$ at $4^{\circ} \mathrm{C}$ 


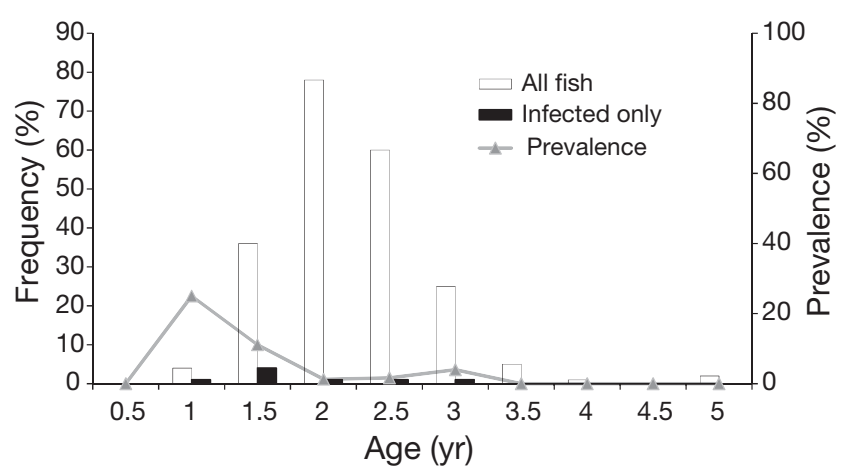

Fig. 4. Merlangius merlangus. Frequency of age classes sampled for individual processing and infection prevalence. Ages were estimated from von Bertalanffy equation reported (Ciloglu et al. 2001) from whiting in the same region

low levels of VHSV that could be detected during winter months in 2007 and 2008.

In our study, at most 2 out of 10 pools were found to be positive for VHSV during March of 2007. Individual prevalence estimated from pooled samples, using the methods described in Kline et al. (1989) and Hauck (1991), were also low (3.14\%). The upper percentile (97.5), on the other hand, was more than 3 times the estimated prevalence. In accordance with the upper percentiles, higher prevalences $7 \%$ in February and $5 \%$ in March) in the individual sampling were observed. The level of virus in infected individuals was generally very low (less than $10^{2} \mathrm{TCID}_{50} \mathrm{ml}^{-1}$ ). Thus, the difference between the prevalence observed and that estimated could be due to the dilution effect as a result of pooling, as also suggested by Kline et al. (1989).

Low levels of VHSV prevalence in the whiting population in the absence of signs of disease and low levels of virus seem to be characteristic of the infection in whiting in the southeastern Black Sea. Similarly, Mortensen et al. (1999) reported that whiting in the Baltic Sea were also asymptomatic carriers of VHSV.

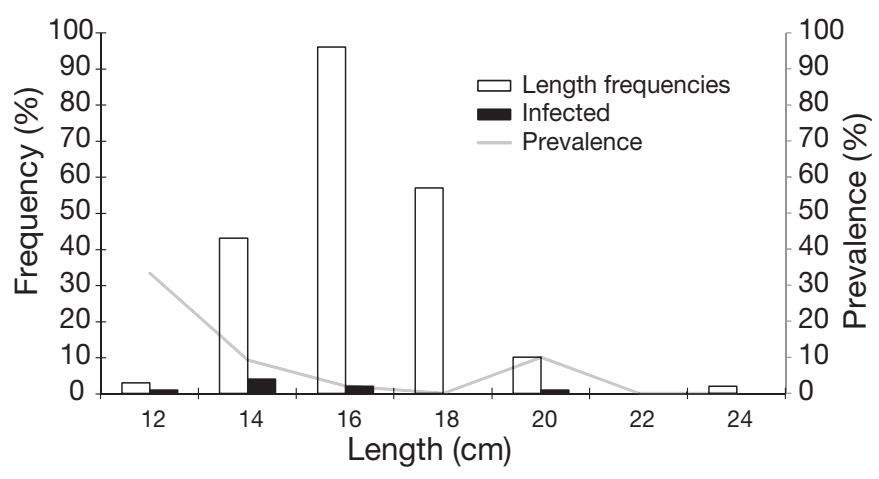

Fig. 5. Merlangius merlangus. Frequency of length classes sampled for individual testing and infection prevalence at different length classes

Hedrick et al. (2003) reported a high prevalence $(81 \%)$ of infection with a few fish showing clinical signs during a VHS epizootic in a captive group of surf smelt Hypomesus pretiosus pretiosus. Higher levels of prevalence than that observed in the present study could be expected if an epizootic occurs among whiting in the region. However, very low prevalence among older ( 2 yr and above) fish was observed, suggesting whiting carries the virus, which can be detected seasonally in these subclinical carriers. Moreover, the highest prevalence $(7 \%)$ in January occurred suddenly, rather than by a gradual increase. More study is needed to determine whether any of its prey species, especially migratory prey, consumed by whiting during winter carry VHSV.

The age and length frequency data indicate that VHSV prevalence decreases sharply with increase in fish age. In the youngest age group ( $1 \mathrm{yr}$ old), the observed prevalence was $25 \%$, which dropped to $11 \%$ in the second group (1.5 yr old) suggesting that the prevalence among younger $(<1$ yr $)$ fish could be higher. The level of prevalence among brood fish under spawning stress was not as high as expected. It

Table 2. Merlangius merlangus. Summary of sampling scheme in 2009 and results of the viral examinations by sex (M: males; F: females). Condition factor $(\mathrm{CF})=\left(\right.$ weight $\times$ length $\left.^{-3}\right) \times 100$

\begin{tabular}{|c|c|c|c|c|c|c|}
\hline Sample & $\mathrm{n}$ & Number of positives & $\%$ positive & Weight \pm SD $(g)$ & Length $\pm \mathrm{SD}(\mathrm{cm})$ & $\mathrm{CF}$ \\
\hline \multicolumn{7}{|l|}{ January } \\
\hline M & 15 & 1 & 6.67 & $23.23 \pm 10.76$ & $14.06 \pm 1.71$ & 0.83 \\
\hline $\mathrm{F}$ & 28 & 2 & 7.14 & $30.57 \pm 13.28$ & $15.17 \pm 1.93$ & 0.87 \\
\hline \multicolumn{7}{|c|}{ February } \\
\hline M & 26 & 1 & 3.85 & $26.95 \pm 8.68$ & $14.85 \pm 1.41$ & 0.82 \\
\hline $\mathrm{F}$ & 54 & 3 & 5.56 & $32.35 \pm 9.66$ & $15.74 \pm 1.48$ & 0.83 \\
\hline \multicolumn{7}{|l|}{ March } \\
\hline M & 26 & 0 & 0.00 & $26.29 \pm 9.99$ & $14.99 \pm 1.56$ & 0.78 \\
\hline $\mathrm{F}$ & 62 & 1 & 1.61 & $33.11 \pm 14.01$ & $16.09 \pm 1.85$ & 0.93 \\
\hline
\end{tabular}


should be noted that infection rate, i.e. prevalence, was twice as high among females than among males. More data are needed to determine the reservoir for the virus in the system.

VHS has been reported at temperatures ranging from 2 to $20^{\circ} \mathrm{C}$ around the world. Most isolations of VHSV in the Pacific Northwest of the USA were obtained in areas having annual temperatures between 7 and $14^{\circ} \mathrm{C}$ (Hedrick et al. 2003). VHSV was isolated from Japanese flounder Paralichthys olivaceus over a temperature range of 7 to $18^{\circ} \mathrm{C}$ (Takano et al. 2001), and natural epizootics of VHS were reported at 4 to $5^{\circ} \mathrm{C}$ ambient water temperature in Pacific herring Clupea pallasii, Pacific hake Merluccius productus and walleye pollock Theragra chalcogramma in Alaska (Meyers et al. 1994, 1999). In our study, detection of VHSV in whiting demonstrated seasonal variation. At depths of 30 to $45 \mathrm{~m}$, where whiting mostly live, water temperatures are always below $18^{\circ} \mathrm{C}$ throughout the year, indicating that environmental temperature is not a limiting factor for replication of VHSV. Bellet (1965) suggested that exposure to cold water could be an important factor in the occurrence of the disease in rainbow trout, and similarly Hedrick et al. (2003) reported that low water temperature was a significant stressor for sardine Sardinops sagax. In our study, VHSV was initially detected in whiting at the lowest surface water temperatures. In the present study, bottom temperatures were higher than surface temperatures at the beginning of the detection period. Then bottom temperatures dropped significantly during the period of May through August. However, VHSV was not isolated during these low temperature periods. Apparently, an increase in the bottom temperatures up to $17^{\circ} \mathrm{C}$ and then a drop to $12^{\circ} \mathrm{C}$ might have effectively stressed the fish, predisposing them to VHSV.

Exposing virus to $26^{\circ} \mathrm{C}$ for $7 \mathrm{~h}$ did not have any effect on its viability indicating that any virus present in our samples would not have been affected by the short exposure to elevated temperatures during the sampling process.

Condition factors of whiting during the VHSVpositive season (February to April) dropped more than $13 \%$, but increased again at the end of the season, indicating an exposure to a potential stressor, e.g. factors related to feeding or other disease exposure. Ogut \& Palm (2005) reported from the same area that the prevalence of a trichodinid species on whiting peaked (>90\%) with high mean intensities ( 60 parasites per gill arch per host) around February. The parasite mean intensity increased from February to April, similar to the trends of VHSV, and then a gradual decrease through June was anticipated. Observance of a high parasite load is also an indication of highly stressed fish during the period when VHSV was observed. This observation provides further evidence that VHSV is not a major pathogen causing disease in whiting. It is also possible that whiting acquire VHSV from feeding heavily on a prey during this period.

In the last decade, culture of rainbow trout in sea cages has intensified in the southeastern Black Sea. The presence of VHSV-carrying wild fish species in the region increases the disease risk to the farmed rainbow trout, so industry practices to reduce this risk should be established and maintained. VHSV has not been reported in trout in fresh water in Turkey. However, this does not mean that the transfer will not occur in the future. To prevent transfer of virus to rainbow trout hatcheries, rainbow trout in the Black Sea should not be transferred back to the freshwater hatcheries, as suggested by Skall et al. (2005).

In conclusion, the data collected from a key prey species, whiting, strongly suggest that VHSV is endemic in the Black Sea region. Detectable levels of VHSV in whiting occurred in winter months indicating some seasonal influences. More study is needed to determine the effect of the virus on predators of whiting and on species used in coastal aquaculture.

Acknowledgements. Funds for this project were provided by Karadeniz Technical University (\#2005.117.001.4)

\section{LITERATURE CITED}

Bellet R (1965) Viral haemorrhagic septicaemia (VHS) of the rainbow trout bred in France. Ann NY Acad Sci 126: 461-467

Ciloglu E, Sahin C, Zengin M, Genc Y (2001) Determination of some population parameters and reproduction period of whiting (Merlangius merlangus euxinus Nordmann, 1840) on the Trabzon-Yomra coast in the eastern Black Sea. Turk J Vet Anim Sci 25:831-837

Cowling DW, Gardner IA, Johnson WO (1999) Comparison of methods for estimation of individual-level prevalence based on pooled samples. Prev Vet Med 39:211-225

> Einer-Jensen K, Ahrens P, Forsberg R, Lorenzen N (2004) Evolution of the fish rhabdovirus viral haemorrhagic septicaemia virus. J Gen Virol 85:1167-1179

Fijan N, Sulirnanovic D, Bearzotte M, Muzinic D and others (1983) Some properties of the epithelioma papulosum cyprinid (EPC) cell line from carp Cyprinus carpio. Ann Virol (Inst Pasteur) 134E:207-220

> Gastric J, de Kinkelin P (1980) Occurrence of viral haemorrhagic septicaemia in rainbow trout Salmo gairdneri Richardson reared in sea-water. J Fish Dis 3:21-27

Hauck WW (1991) Confidence intervals for seroprevalence determined from pooled sera. Ann Epidemiol 1:277-281

Hedrick RP, Batts WN, Yun S, Traxler GS, Kaufman J, Winton JR (2003) Host and geographic range extensions of the North American strain of viral haemorrhagic septicaemia virus. Dis Aquat Org 55:211-220

Hill B (1992) Impact of viral diseases on salmonid fish in Europe. In: Kimura T (ed) Proceedings of the OJI international symposium on salmonid diseases. Hokkaido University Press, Sapporo, p 48-59 
Jensen MH (1963) Preparation of fish tissue cultures for virus research. Bull Off Int Epizoot 59:131-134

Jensen MH (1965) Research on the virus of Egtved disease. Ann NY Acad Sci 126:422-426

Jensen NJ, Bloch B, Larsen JL (1979) The ulcus-syndrome in cod (Gadus morhua). III. A preliminary virological report. Nord Vet Med 31:436-442

Jørgensen PEV, Olesen NJ (1987) Cod ulcus syndrome rhabdovirus is indistinguishable from the Egtved (VHS) virus. Bull Eur Assoc Fish Pathol 7:73-74

Kline RL, Brothers TA, Brookmeyer R, Zeger S, Quicc TC (1989) Evaluation of human immunodeficiency virus (HIV) seroprevalence in population surveys using pooled sera. J Clin Microbiol 27:1449-1452

Meyers TR, Short S, Lipson K, Batts WN, Winton JR, Wilcock J, Brown E (1994) Association of viral haemorrhagic septicaemia virus with epizootic hemorrhages of the skin in Pacific herring Clupea harengus pallasi from Prince William Sound and Kodiak Island, Alaska, USA. Dis Aquat Org 19:27-37

Meyers TR, Short S, Lipson K (1999) Isolation of the North American strain of viral haemorrhagic septicaemia virus (VHSV) associated with epizootic mortality in two new host species of Alaskan marine fish. Dis Aquat Org 38:81-86

Mortensen HF, Heuer OE, Lorenzen N, Otte L, Olesen NJ (1999) Isolation of viral haemorrhagic septicaemia virus (VHSV) from wild marine fish species in the Baltic Sea, Kattegat, Skagerrak and the North Sea. Virus Res 63:

Editorial responsibility: Mark Crane,

Geelong, Victoria, Australia
95-106

> Nishizawa T, Savas H, Isidan H, Ustundag C, Iwamoto H, Yoshimizu M (2006) Genotyping and pathogenicity of viral haemorrhagic septicaemia virus from free-living turbot (Psetta maxima) in a Turkish coastal area of the Black Sea. Appl Environ Microbiol 72:2373-2378

> Ogut H, Palm HW (2005) Seasonal dynamics of Trichodina spp. on whiting (Merlangius merlangus) in relation to organic pollution on the eastern Black Sea coast of Turkey. Parasitol Res 96:149-153

OIE (2009) Ch. 2.3.9, Viral haemorrhagic septicaemia. In: Manual of diagnostic tests for aquatic animals. OIE, Paris, p 279-298. www.oie.int/eng/normes/fmanual/2.3.09. VHS.pdf

Olesen NJ (1998) Sanitation of viral haemorrhagic septicaemia (VHS). J Appl Ichthyol 14:173-177

Skall HF, Olesen NJ, Mellergaard S (2005) Viral haemorrhagic septicaemia virus in marine fish and its implications for fish farming - a review. J Fish Dis 28:509-529

Smail DA (1999) Viral haemorrhagic septicaemia. In: Woo PTK, Bruno DW (eds) Fish diseases and disorders: viral, bacterial and fungal infections, Vol 3. CAB International, New York, p 123-147

Takano R, Mori K, Nishizawa T, Arimoto M, Muroga K (2001) Isolation of viruses from wild Japanese flounder Paralichthys olivaceus. Fish Pathol 36:153-160

Wolf K (1988) Fish viruses and fish viral diseases. Comstock Publishing Associates, Cornell University Press, Ithaca, NY

Submitted: March 30, 2009; Accepted: October 1, 2009

Proofs received from author(s): January 14, 2010 